\title{
THE BANK LENDING CHANNEL OF MONETARY POLICY TRANSMISSION IN A DUAL BANKING SYSTEM
}

\author{
Mansor H. Ibrahim ${ }^{1}$
}

\begin{abstract}
This paper examines the impact of monetary policy on bank lending in a dual banking system, i.e. Malaysia. Making use of an unbalanced panel data set of 38 Islamic and conventional banks covering mostly 2001-2014, we find evidence that variations in monetary policy affect lending growth of Islamic banks and, to some extent, conventional banks. The results further reveal that, in conformity with studies using aggregate Islamic financing data, the Islamic financing growth reacts more strongly to monetary policy changes. Moreover, we find no marked difference between full-fledged Islamic banks and Islamic bank subsidiaries in their responses to monetary policy. While we also document some evidence indicating the significant relations between bankspecific variables and lending growth, the bank-specific variables do not seem to have any role in impacting the potency of the bank lending channel. Finally, we find that lending growth is directly related to economic growth, suggesting procyclicality of bank lending/financing in Malaysia. These results have important implications for effective implementation of monetary policy and further development of Islamic banks in Malaysia.
\end{abstract}

Key words: Bank lending channel, Monetary policy, Dual banking system, Malaysia

JEL Classification: E53, G21, C23

Received: September 17, 2016; Revised: January 12, 2017;

Accepted: February 3, 2017

1 School of Graduate Studies, International Centre for Education in Islamic Finance, Lorong Universiti A, 51200 Kuala Lumpur, Malaysia. Email: mansorhi@inceif.org 


\section{INTRODUCTION}

\subsection{Background}

In this paper, we examine the impact of monetary policy on bank lending in Malaysia taking explicitly the Islamic banking model into consideration. Propelled by the government's initiatives to be the international centre of Islamic finance, the Islamic banking sector in Malaysia has witnessed rapid development especially since the 1997/1998 Asian financial crisis. From only one Islamic bank established in 1983, the sector presently comprises 6 full-fledged Islamic banks ( 3 domestic and 3 foreign) and 11 Islamic bank subsidiaries of conventional banks. ${ }^{2}$ The Islamic financing share has over the years increased substantially from slightly above $5 \%$ of the total banking loans in 2000 to more than $25 \%$ in 2015 and, at the present pace, it is expected to reach a target of $40 \%$ share by 2020 . Given the everincreasing importance of the Islamic banking sector in Malaysia, the natural questions that arise are how it fits into the present monetary framework and whether it has a contributive role to monetary transmission mechanisms. More precisely, the question is: Do Islamic banks play a part in amplifying monetary impulses as posited by the bank lending channel of monetary transmission mechanisms?

The bank lending channel stems from market imperfections and imperfect substitutability of financial assets. It posits that, in the presence of financial frictions and market imperfections, banks have limited ability to raise uninsured liabilities to offset any decline in bank deposits, the main source of loanable fund, and maintain their loan supply. In other words, facing contractionary monetary policy, the banks are forced to curtail their loan supply (Bernanke \& Blinder, 1988). Disyatat (2011) further notes that monetary policy may also influence banks' external finance premium, which may further constrain bank loan supply especially from banks with weak balance sheet. Subsequently, with limited access to alternative sources of financing, bank-dependent households and firms are compelled to cut down their consumption and

2 The full-fledged Islamic banks in Malaysia include two domestic commercial banks (Bank Islam Malaysia, Bank Muamalat), three foreign commercial banks (Al-Rajhi Bank, Asian Finance House, and Kuwait Finance House), and one domestic cooperative bank (Bank Kerjasama Rakyat Malaysia). 
production. The presence of the lending channel complements and amplifies the real effects of monetary policy that work through the interest rate and other channels and renders monetary policy distributional consequences. The latter refers to the unequal effects of monetary policy on different banks and different sectors of the economy. Notably, banks with weak balance sheet and sectors and firms with no access to other sources of finance, especially households and small firms, will be more affected by monetary policy changes.

Addressing the lending/financing channel for Islamic banks is timely. The Islamic banking sector has developed rapidly in especially Malaysia, as highlighted above, and the Middle East and has also received increasing acceptance in even non-Muslim world. It is expected that, at its current pace of progress, the Islamic banking sector will be even more important in the future. Accordingly, it would be important for policy makers to gauge the strength of monetary transmissions through Islamic banks for effective implementation of monetary policy. Moreover, the analysis of Islamic bank financing is necessary for future development of Islamic banking. In the literature, it is well understood that the bank lending channel is intensified in less developed financial markets and is tied fundamentally to such bank characteristics as size, capitalization and liquidity. Accordingly, the presence of Islamic lending/financing channel signals the need for further development of Islamic financial markets and improvements of Islamic banks' balance sheet positions to alleviate problems of asymmetric information and market imperfections.

Existing studies on the lending channel in a dual-banking system has mainly analysed aggregate lending data (Kassim, Majid, \& Yusof, 2009; Sukmana \& Kassim, 2010; Ibrahim \& Sukmana, 2011; Ergec \& Arslan, 2013). Hence, their results are subject to a wellknown identification problem, i.e. whether the changes in bank loans in response to changes in monetary policy indicator reflects changes in loan supply or loan demand (Kashyap \& Stein, 2000). We add to this literature by focusing on bank-level data. The few related studies that have emerged in recent years to look at Islamic bank financing and its relation to monetary policy at the bank level produce mixed results and hence urge for further investigation. At the same time, they make no attempt to distinguish between full- 
fledged Islamic banks and Islamic bank subsidiaries of conventional banks. In the Malaysian context, the Islamic bank subsidiaries of conventional banks are more dominant than the full-fledged Islamic banks in terms of number and size (Ariff, 2015). As the former are tied to their conventional parent banks, their business decisions are more likely in tandem with their parent banks. Most importantly in our context, being under the same umbrella, they are likely to be rated similarly as their conventional parent banks. On this basis, there may be potential differences between the fullfledged Islamic banks and Islamic bank subsidiaries of conventional banks in their monetary transmission role, an aspect that we also add into the analysis of the bank lending channel.

We employ unbalanced panel data of 38 banks (17 Islamic banks and 21 conventional banks) covering the period from 2001 to 2014. Modelling bank lending equation in a dynamic form, we adopt the GMM estimators to ensure consistencies of our estimates. The rest of the paper is structured as follows. In the next section, we review related literature. Then, section 3 describes the models. Section 4 presents the data and discusses estimation results. Finally, we conclude with the main findings and some concluding remarks.

\section{RELATED LITERATURE}

Changes in monetary policy are transmitted to the real sector through various channels, among which include the interest rate, exchange rate, asset prices and credit channels. The bank lending channel falls under the credit channel, normally termed credit view of monetary transmissions. It is based on a premise that banks face financial frictions and market imperfections and hence imperfect substitutability of banks' reservable deposits and uninsured liabilities. The drain in bank deposits due to contractionary monetary policy would thus force banks to contract loan supply. This would mean that those sectors and firms that are dependent on bank loans have to cut down their production if they cannot seek alternative sources of funds. The bank lending channel complements the other channels of monetary transmissions and in the process, apart from having unequal effects on different economic sectors, amplifies aggregate fluctuations. Accordingly, it is critical to assess the 
potency of this channel for proper implementation of monetary policy.

An assessment of the bank lending channel requires identification of shift in loan supply and shift in loan demand in responses to monetary policy changes. This so-called identification problem is the main criticism levied against early studies employing aggregate data to examine the bank lending channel (Kashyap \& Stein, 2000). Subsequently, many studies have employed bank-level data and exploited bank-specific characteristics to identify shift in loan supply and, hence, the presence of the bank lending channel. The argument is the lending decision by banks would depend critically on bank-specific characteristics or balance sheet strength. Accordingly, the different responses of banks with different bankspecific characteristics to monetary policy changes would signify shift in loan supply. Among the various characteristics, bank size, capitalization and liquidity have been identified to be central. It is argued that small banks are likely to face more information asymmetry and less liquid and less capitalized banks have less ability to insulate themselves from shocks in deposits and, accordingly, they are more likely adversely affected by contractionary monetary policy.

Studies of the U.S. banks and to some extent the European banks provide confirmative evidence for the important role of these bank characteristics and the presence of the bank-lending channel. For instance, using the U.S. bank-level data, Kishan and Opiela (2000) find small banks to be affected more by monetary policy changes. Analyses by Kakes and Sturm (2002) for the German banks and Jimborean (2009) and Matousek and Sarantis (2009) for the CEE banking sector reach a similar conclusion. Examples of studies using the U.S. and European bank-level data that provide support for the importance of bank capital strength in the bank lending channel include Peek and Rosengren (1995), Kishan and Opiela (2000, 2006), Altunbas, Fazylov and Molyneux (2002), and Gambacorta (2005). Among the previous mentioned studies, Gambacorta (2005) and Matousek and Sarantis (2009) also find bank liquidity to be central, collaborating early works on the U.S. by Stein (1998) and Kashyap and Stein (2000). 
The interest in the bank lending channel has also directed researchers to look for other potential bank-specific characteristics that may account for different responses of banks to monetary policy. As noted by Altunbas, Gambacorta and Marques-Ibanez (2010), the standard bank-specific factors used in previous studies may no longer be adequate due to changing financial landscape and financial innovations. Among the factors that have been considered include ownership (Bhaumik, Dang, \& Kutan, 2011), competition (Olivero, Li, \& Jeon, 2011; Yang \& Shao, 2016), securitization (Altunbas, Gambacorta, \& Marques-Ibanez, 2009; Gambacorta \& Marquez-lbanez, 2011), off-balance sheet activities (Perera, Ralston, \& Wickramanayake, 2014), risk (Altunbas et al., 2010), and country risk premium (Cantero-Saiz, Sanfilippo-Azofra, Torre-Olmo, \& Lopez-Gutierrez, 2014). Evidence from these studies suggest the significance of these factors in influencing loan reaction to monetary policy.

Being the fastest growing segment of the financial market, the Islamic banking sector has captivated much attention recently. While increasing number of studies have empirically compared the Islamic banking system with the well-established conventional banking system in terms of efficiency, performance and resilience to crises (Cihak \& Hesse, 2010; Hasan \& Dridi, 2010; Beck, DemirgucKunt, \& Merrouche, 2013; Bourkhis \& Nabi, 2013), our understanding of the role Islamic banks play in monetary transmission remains thin. Khatat (2016) acknow-ledges complexity in assessing the monetary transmission in a dual banking system but, at the same time, envisages the potential of conventional channels of transmission particularly the bank lending/financing channel via the Islamic banking segment. According to Khatat (2016), the Islamic banks are not insulated from macroeconomic and financial environments in which they operate. Hence, the bank lending channel may be operative through Islamic banks as well in so far as the policy actions influence the Islamic credit supply. However, whether the bank lending channel via the Islamic banks will be more or less potent would depend on various factors including the size of the Islamic banking sector, jurisdiction, structure of contracts and Islamic banks' consumer behaviour (Khatat, 2016). 
It is plausible that, in light of the premises underlying the bank lending channel and the current state of the Islamic banking development, the bank lending channel is stronger via the Islamic banks. It is well acknowledged that the potency of the bank lending channel and its underlying information imperfections are negatively related to stages of financial or banking development. Being less developed, the Islamic banking sector lacks substitutable sources of funds for Islamic deposits. Accordingly, Islamic banks are likely to face constraints in maintaining financing supply in the face of monetary policy shocks. By contrast, being more developed, the conventional banks may have better access to alternative sources of funds and hence are able to mitigate the impacts of monetary policy shocks on their loan supply. Furthermore, in a dual-banking system, Islamic banks face the so-called displaced commercial risk or interest rate risk, i.e. the risk of deposits flowing from Islamic banks to conventional banks in the face of increasing interest rate. This means that monetary policy tightening may further limit Islamic bank financing unless depositors, driven by religious reasons, stay put with the Islamic banks (see also Zaheer, Ongena, \& van Wijnbergen, 2013).

In the literature, various studies have examined the sensitivity of aggregate Islamic financing to interest rate variations and find evidence that Islamic banks are excessively sensitive to interest rates (Kassim et al., 2009; Sukmana \& Kassim, 2010; Ibrahim \& Sukmana, 2011; Ergec \& Arslan, 2013). These results cannot definitely be construed as validating the bank lending channel given the aforementioned identification problem. Very few studies have looked at the bank-level data of the banking sector in a dual banking system, i.e. in a country that has both Islamic banks and conventional banks. These include Macit (2012) for Turkey, Zaheer et al. (2013) for Pakistan, and Zulkhibri (2013) and Asbeig and Kassim (2015) for Malaysia.

Macit (2012) examines the Turkish banking system using quarterly bank-level data from 2006 to 2010. He finds the bank lending channel to be operative for both conventional and Islamic banks. The contraction of loan growth in response to contractionary monetary policy is however found to be larger for Islamic banks. The analysis by Zaheer et al. (2013) for the case of Pakistan, however, documents weakened bank lending channel through the 
Islamic banks. Using quarterly data from 2002.Q2 to 2010.Q1, they find Islamic banks to maintain their financing following a monetary contraction. In the case of Malaysia, Zulkhibri (2013), finds the bank lending channel to be operative via small and low liquidity banking institutions. Most recently, examining Malaysian bank-level data, Asbeig and Kassim (2015) find no evidence for the bank lending channel for both Islamic and conventional banks. Their results, however, are based on separate estimation of a sample of 11 Islamic banks and a sample of 13 conventional banks. In the present paper, we seek to add further to this limited literature.

\section{EMPIRICAL MODELS}

We specify a bank lending equation relating the growth of bank loans to a monetary policy variable and a vector of controlled variables in line with the literature on the bank lending channel of monetary transmission mechanisms (Jimborean, 2009; Matousek \& Sarantis, 2009; Altunbas et al., 2009, 2010; Bhaumik et al., 2011; Olivero et al., 2011; Cantero-Saiz et al., 2014; Apergis \& Christou, 2015; Yang \& Shao, 2016). We begin the analysis with the basic model written as:

$$
\begin{gathered}
\Delta \ln \left(L_{i t}\right)=\alpha_{i}+\gamma \Delta \ln \left(L_{i t-1}\right)+\beta \Delta R_{t}+\sum_{j=1}^{k} \theta_{j} B S_{i t-1}+ \\
\delta \Delta \ln \left(G D P_{t}\right)+\tau I N F_{t}+\varepsilon_{i t}
\end{gathered}
$$

where $L$ is gross loans, $R$ is interest rate representing monetary policy, BS is a vector of bank-specific variables, GDP is real gross domestic product, INF is inflation rate, In stands for natural logarithm, and is the first-difference operator. The once-lagged dependent variable is included to allow persistence in the bank lending behaviour. The growth rate of real GDP ( InGDF) and INF represent respectively cyclical fluctuations and uncertainty in real activities, the inclusion of which is to isolate monetary policy shocks and capture the influences of demand factors on bank lending. We consider five bank-specific variables, namely, bank size (SIZE), bank capitalization (EQA), bank liquidity (LIQA), bank funding (FUND), and asset quality or risk as measured by the loan loss reserve ratio (LLRR). The first three bank-specific variables are standard. Bank 
funding is to incorporate the importance of customer deposits as a source of funding, which is noted to be pertinent for especially Islamic banks (Ibrahim, 2016). Meanwhile, the inclusion of the LLRR follows Altunbas et al. (2010) that bank risk is important in shaping bank lending behaviour. Note that the bank-specific variables are lagged one period to address the endogeneity issue. Heterogeneities among banks stemming from other bank-specific factors are captured by bank-specific effects, i.e. $\alpha_{i}$.

Consistent with Gambacorta (2005), Matousek and Sarantis (2009), Cantero-Saiz et al. (2014), Yang and Shao (2016) and others, we normalize the bank-specific variables with their average across all banks as:

$$
\begin{aligned}
& S I Z E_{i t}=\ln A_{i t}-\frac{\sum \ln A_{i t}}{N_{t}} \\
& E Q A_{i t}=\frac{E_{i t}}{A_{i t}}-\frac{1}{T} \sum_{t}\left(\frac{1}{N_{t}} \sum_{i} \frac{E_{i t}}{A_{i t}}\right) \\
& L I Q A_{i t}=\frac{L I Q_{i t}}{A_{i t}}-\frac{1}{T} \sum_{t}\left(\frac{1}{N_{t}} \sum_{i} \frac{L I Q_{i t}}{A_{i t}}\right) \\
& F U N D_{i t}=\frac{D_{i t}}{L I A B_{i t}}-\frac{1}{T} \sum_{t}\left(\frac{1}{N_{t}} \sum_{i} \frac{D_{i t}}{L I A B_{i t}}\right) \\
& L L R R_{i t}=\frac{L L R_{i t}}{L_{i t}}-\frac{1}{T} \sum_{t}\left(\frac{1}{N_{t}} \sum_{i} \frac{L L R_{i t}}{L_{i t}}\right)
\end{aligned}
$$

where $A$ is total assets, $E$ is total equity, $L I Q$ is liquid assets, $D$ is total deposits, $L I A B$ is total liabilities, and $L L R$ is total loan loss reserves. As will be explained later, this normalization eases our interpretation when the model is extended to include the interactions between bank-specific variables and monetary policy changes.

In order to assess whether Islamic financing is less or more sensitive to monetary policy changes and to allow for the influences of bank-specific characteristics on the potency of the lending channel, we extend the basic equation to include interaction terms as: 


$$
\begin{aligned}
\Delta \ln \left(L_{i t}\right)=\alpha_{i}+ & \gamma \Delta \ln \left(L_{i t-1}\right)+\beta_{1}\left(\Delta R_{t} \times I B_{i}\right)+\beta_{2}\left(\Delta R_{t} \times C B_{i}\right) \\
& +\sum_{j=1}^{k} \theta_{j} B S_{i t-1}+\sum_{j=1}^{k} \vartheta_{j}\left(B S_{i t-1} \times \Delta R_{t}\right) \\
& +\delta \Delta \ln \left(G D P_{t}\right)+\tau I N F_{t}+\varepsilon_{i t}
\end{aligned}
$$

where $I B$ and $C B$ are Islamic bank dummy and conventional bank dummy respectively. The parameter $\beta_{1}$ measures the effect of monetary policy changes on Islamic bank financing while $\beta_{2}$ represents the sensitivity of conventional lending to monetary policy. Both are expected to be negative. As explained in CanteroSaiz et al. (2014), the use of normalized bank-specific variables eases interpretation of (7) since the mean of the interaction terms involving the bank-specific variables equals zero. Accordingly, $\beta_{1}$ $\left(\beta_{2}\right)$ can be interpreted as the average effect of monetary policy on Islamic financing (conventional lending) growth. Meanwhile, the coefficients of the bank-specific variables $\left(\theta_{j}: j=1, \ldots, 5\right)$ measure the effects of the corresponding bank variables on loan growth when there is no changes in monetary policy. The coefficients of the interactions between bank-specific variables and monetary policy reflect the differential effect of the included bank variables on the reaction of bank lending/financing to monetary policy changes.

We further entertain the possibility that the potency of the bank lending/financial channel is different for Islamic full-fledged banks and Islamic bank subsidiaries. Arguably, being tied to their conventional parent banks, Islamic bank subsidiaries may have informational benefits over the full-fledged Islamic banks and may act more in tandem with their parent banks. To this end, we further extend the equation to:

$$
\begin{gathered}
\Delta \ln \left(L_{i t}\right)=\alpha_{i}+\gamma \Delta \ln \left(L_{i t-1}\right)+\beta_{11}\left(\Delta R_{t} \times I B F_{i}\right)+\beta_{12}\left(\Delta R_{t} \times\right. \\
\left.I B S_{i}\right)+\beta_{2}\left(\Delta R_{t} \times C B_{i}\right)+\sum_{j=1}^{k} \theta_{j} B S_{i t-1}+ \\
\sum_{j=1}^{k} \vartheta_{j}\left(B S_{i t-1} \times \Delta R_{t}\right)+\delta \Delta \ln \left(G D P_{t}\right)+\tau I N F_{t}+\varepsilon_{i t}
\end{gathered}
$$

where IBF is a full-fledged Islamic bank dummy and IBS is Islamic bank subsidiary dummy. The interpretation of the interactive 
dummies' coefficients can be made in a similar manner as explained above.

To obtain consistent and efficient estimates of the model parameters, we adopt the first-difference and system GMM (Generalized Methods of Moments) estimators as proposed by Arellano and Bond (1991), Arellano and Bover (1995), and Blundell and Bond (1998). In a dynamic panel specification, the non-zero correlation between the lagged dependent variable and individual-specific effect gives rise to endogeneity problem and renders traditional panel least squares estimators inappropriate. Arellano and Bond (1991) suggest differencing the model and then employ internal instruments, i.e. lagged level variables, as instruments to address endogeneity issue. The approach is known as the first-difference GMM estimator. Arellano and Bover (1995) and Blundell and Bond (1998) further suggest combining level specification with its firstdifference version as a system such that the information contained in the level relationship will not be lost. Due to their ability to address the endogeneity issue, we employ both first-difference and system GMM estimators in our analysis. We check the consistency of our estimates by verifying the relevance of the instruments and absence of second-order auto correlation using the Hansen test for instrument validity and Arellano-Bond auto-correlation test. Since too many instruments can reduce the power of the Hansen test (Seven and Yetkiner, 2016), we limit the number of instruments such that it is less than the number of cross-sectional units (Roodman, 2009). In all the estimation, the two-step procedure and robust standard errors using the Windmeijer's (2005) finite sample correction are used.

\section{DATA AND RESULTS}

This section first describes the data used in the analysis. Then, the results are presented and discussed. Four sets of regressions are performed. The first set of regressions relates to estimation of equation (1) (Table 3). The next two sets introduce Islamic bank and conventional bank dummies to evaluate the relative strength of the channel of the Islamic banks vis-à-vis conventional banks (Table 4 and Table 5). The final set of regressions further examines whether bank-specific variables play any role in the transmission mechanism 
and, at the same time, assesses the robustness of our main theme (Table 6).

\subsection{Data Descriptions}

Data on bank-related variables for Malaysia's commercial banks and Islamic banks are from Bureau van Dijk's Bankscope database. Requiring at least five consecutive years of data for each bank and excluding bank-year observations of merged banks, we arrive at an unbalanced panel sample of 21 conventional banks and 17 Islamic banks covering the period 2001-2014. We use the overnight interbank rate to represent the monetary policy variable in line with Domac (1999) and Ibrahim (2005). Output growth is the growth rate of real gross domestic product and the inflation rate is computed from the consumer price index. The overnight interbank rate is sourced from the Monthly Statistical Bulletin published online by Malaysia's Central Bank, i.e. Bank Negara Malaysia (www.bnm.gov.my). Meanwhile, we obtain the GDP growth rate and inflation rate from the World Bank's World Development Indicators database.

Table 1 reports descriptive statistics of bank-related variables before normalization. Over the sample period, the average growth of Islamic financing far exceeds that of conventional bank lending, i.e. $20.7 \%$ against $9.4 \%$. We may also note that conventional banks are on average larger as measured by total assets, are better capitalized, are more liquid, and have higher loan loss reserves. The funding ratio, measured by total deposits to total liabilities, is however higher for Islamic banks. Thus, the Islamic banks in Malaysia depend more on deposits as a source of funding. Though not given in the Table, it is worthwhile to mention that over the period 2001-2014, Malaysia grew by more than 5\% per year and recorded average inflation rate of $2.2 \%$. While Malaysia did feel the heat from the global financial crisis witnessing mild contraction of its real activities in 2009, it sailed through the episode well with acceleration of economic growth by more than 7\% in 2010 .

In Table 2, we report pairwise correlations between loan growth, normalized bank-specific variables, macroeconomic variables and monetary policy variable. While these correlations are 
only indicative or preliminary, they are useful in gauging potential multicollinearity among the explanatory variables. On this, several observations are notable. First, the correlations among the bankspecific variables are quite high but still below 0.50 for most cases. We believe that this should not create much problem since they are not exceeding $0.80 .^{3}$ Second, the bank-specific variables seem to be marginally correlated with macroeconomic and monetary variables. Third, the monetary policy variable is highly correlated with real GDP growth (0.786) as well as with inflation (0.460). The inclusion of these macroeconomic variables is thus necessary to isolate real activity shocks impacting interest rate changes from monetary policy shock such that evaluation of the bank lending channel can be made. And finally, pair-wise, lending growth is positively correlated with all variables except bank size, capitalization and loan loss reserves. Taking these statistics as preliminary, we proceed to the formal analysis next.

\subsection{Estimation Results}

We first present the first-difference GMM and system GMM estimation results of the basic equation, i.e. equation (1), in Table 3. The Arellano-Bond autocorrelation test statistics reported at the bottom of the Table indicate the presence of first-order autocorrelation and absence of second order autocorrelation in the first-differenced residuals. Moreover, the Hansen statistics fail to reject the over-identifying restrictions for instrument validity. Accordingly, given that these two tests are satisfied, the coefficient estimates are consistent.

From the estimation results, we document no marked difference between the first-difference GMM and system GMM estimates except on the effects of bank size and loan loss reserve on bank lending. While the first-difference GMM suggests negative and significant coefficient of size, the system GMM indicates its insignificance or even a positive relation to lending growth. The negative relation between bank size and lending growth contradicts Zulkhibri (2013) and Asbeig and Kassim (2015) but

3 Our examination of the Variance Inflation factor (VIF) reveals that it is far below 10 for all variables, which substantiates our contention that multicollinearity is not a concern in our case. 
conforms to the most recent study by Ibrahim (2016). In recent years, there have been much changes in the banking sector and, as explained by Ibrahim (2016), larger banks involve more in nonintermediation activities, which tend to limit their credit growth. The coefficient of the loan loss reserves is found to be positive and significant only when the system GMM is used. The results also suggest that banks that are more liquid and have higher ratio of deposits to liabilities tend to lend more, which conform to the findings respectively by Zulkhibri (2013) and Ibrahim (2016). Bank lending in Malaysia is also found to be pro-cyclical as manifested by the positive and significant coefficient of the real GDP growth in all regressions. Finally, central to our theme, we find the coefficient of the monetary policy changes to be negative and significant at better than $5 \%$ significance level when estimated using the firstdifference GMM. When the system GMM is applied, the coefficient of the interest rate changes remains negative but significant at $10 \%$ in only one regression. We take these results as a first piece of evidence that Malaysia's monetary policy is likely to have significant impact on bank lending.

To further verify whether the impact of monetary policy on bank loans is different for Islamic banks, we proceed to estimating the extended equation as specified in (7) and (8). Since we are interested in whether the Islamic banks are different in their monetary transmission roles, we ignore first the interactions between monetary policy and bank-specific characteristics. The analysis of the influences of bank-specific characteristics on the potency of monetary policy will be carried out later as a robustness check of our main theme. The results of the estimation are given in Table 4 and Table 5. Table 4 demarcates banks into Islamic banks (IB) and conventional banks (CB) and introduces their interactions with monetary policy in the regressions. Meanwhile, Table 5 further subdivides Islamic banks into full-fledged Islamic banks (IBF) and Islamic bank subsidiaries of conventional banks (IBS). As may be seen at the bottom panel of each table, the diagnostic statistics verify the consistency of our GMM estimates.

The results from Table 4 are revealing in suggesting the potency of the bank lending channel via Islamic banks. The coefficient of the interaction term between changes in the interest 
rate and Islamic bank dummy is negative and significant at better than $5 \%$ significant level. However, we uncover weak support for the influences of monetary policy on conventional bank loans. While the coefficient of interest rate - conventional bank dummy interaction is negative, it is significant only in two out of the 8 regressions. Looking at the estimates, we may further infer that the reaction of Islamic bank financing to monetary policy changes is stronger. These results reaffirm early finding using aggregate data that Islamic banks are on average more sensitive to interest rate changes (Kassim et al., 2009; Sukmana \& Kassim, 2010; Ibrahim \& Sukmana, 2011; Ergec \& Arslan, 2013). As highlighted earlier, Islamic banks rely more on customer deposits and, as emphasized by Farooq and Zaheer (2015), have limited access to alternative sources of funds other than deposits during adverse shocks. Moreover, being new in the industry, Islamic banks are likely to face more financial frictions. By contrast, being well-established, conventional banks may have lesser limitations. These may explain why the bank lending channel is stronger for the Islamic banks.

When we further partition Islamic banks into full-fledged Islamic banks and Islamic bank subsidiaries, we obtain similar conclusion (Table 5). Namely, both types of Islamic banks cut their financing following monetary policy tightening. Indeed, looking at the estimated coefficients of $\triangle \mathrm{Rt} \times \mid \mathrm{BF}$ and $\triangle \mathrm{Rt} \times \mid \mathrm{BS}$, there are no significant differences between them. The responses of conventional bank lending to interest rate hikes, however, are either nil or substantially lower than the reactions of Islamic bank financing. This means that, against our conjecture, Islamic bank subsidiaries are different from their conventional parent banks when it comes to their lending decisions.

As for other included variables, we find similar results as in the basic regressions. Both estimators are in agreement in pointing to the positive and significant relation between bank liquidity and lending. This is intuitive as more liquid banks are likely to be more willing to extend loans. In addition, we also obtain confirmative evidence that bank lending/financing is procyclical in Malaysia as reflected by the positive and significant coefficient of real GDP growth in all regressions. In line with the basic results, the relation between size and bank lending growth depends on which estimator is used. That is, it is negative and significant in all 
regressions using the first difference $G M M$ and positive but significant in half of the regressions using the system GMM. Take note also that the funding ratio remains significant only under the system GMM. Meanwhile, the evidence for the significance of the asset quality in affecting lending growth is at best weak.

Our final set of the regressions involves introduction of bankspecific variable - monetary policy interactions in the model. Take note that these interactions are included in turn one by one. Given that the first-difference GMM and system GMM estimators yield similar results, we report in Table 6 only the first-difference GMM estimation results. Our conclusions that we make earlier remain robust to this extension of model specification. Namely, (i) Islamic bank financing is relatively more sensitive to monetary policy changes; (ii) bank size and liquidity are robustly related to bank lending with bank size exerting negative influences on lending growth and liquidity positive influences; and (iii) bank lending growth is pro-cyclical. In addition to the confirmation of earlier results, we further note the absence of the included bank-specific characteristics in shaping the potency of the bank lending channel, the results that contradict earlier finding by Zulkhibri (2013).

These results have several policy implications. First, the presence of the bank lending channel means that assessing monetary policy effectiveness on the basis of the traditional interest rate channel as embedded in standard macroeconomic models would not be adequate. In other words, policymakers must be cognizant of the bank lending channel in their monetary policy implementation such that proper evaluation of its effectiveness can be made. Second, the policymakers must also be cautious in their policy implementation given unequal reaction of Islamic banks and conventional banks to monetary policy. Instead of encouraging intermediation via shari'ah-compliant financial services as key to developing Malaysia as an international hub of Islamic finance, monetary policy contraction may dwarf this function of Islamic banks. Finally, since the lending channel stems from financial frictions and market imperfections, the results hint that these problems may be more acute for Islamic banks. Thus, to alleviate the amplified effects of monetary policy shocks via specifically 
Islamic banks, further efforts must be put in place to deepen the Islamic financial markets.

\section{CONCLUSION}

The paper assesses the bank lending channel in a dual-banking system, Malaysia, addressing whether Islamic banks are different in their financing decisions in responses to monetary policy changes. To this end, it employs an unbalanced panel of 38 Islamic and conventional banks and adopts dynamic panel models. Our results suggest that monetary policy does have impacts on bank lending. The evidence further points to stronger reaction of Islamic bank financing as compared to conventional lending to monetary policy shocks. We further find no significant differences between fullfledged Islamic banks and Islamic bank subsidiaries in their responses to monetary policy. These results substantiate existing evidence based on aggregate data suggesting excessive sensitivity of Islamic financing to interest rate changes. While we document significant relations between bank lending and such bank-specific variables as liquidity, size and funding ratio, they play no role in affecting the potency of the bank lending channel. Apart from these results, we also document the important of cyclical fluctuations in real activities in shaping banks' lending decisions.

Our results have important implications. In addition to the need to factor in the presence of the bank lending channel for the proper conduct of monetary policy, attention is much required for further development of the Islamic financial markets. The strength of the lending channel via Islamic banks suggests at least (i) financial frictions and information asymmetry are more acute for the Islamic banking sector and/or (ii) alternative sources of funds are more limited for the Islamic banks. The implications of these are two-folds: (i) the Islamic banks have a role in the amplification of aggregate fluctuations, and (ii) the Islamic banks and their clients would be more adversely affected by monetary policy contraction jeopardizing their roles in society especially pertaining to financial inclusion. As the Islamic banking sector will be systemically more important in the future, these implications of our findings should not be ignored. 
Having said these, we have the following limitations and suggest an avenue for future research. Admittedly, our analysis is confined to the case of Malaysia, whose implications may not be directly applicable to other dual-banking countries that are at different development stages of Islamic banking and finance and have different regulatory framework. We also are not able to perform further analyses as to whether the roles of bank-specific characteristics in affecting the bank lending channel are different across different bank types, Islamic and conventional. More variability in the data is needed for us to introduce additional interaction terms in the model. These limitations suggest further analysis employing cross-country data of the dual banking system, especially for countries that have systematically important Islamic banking sector. 


\section{REFERENCES}

Altunbas, Y., Fazylov, O., \& Molyneux, P. (2002). Evidence on the bank lending channel in Europe. Journal of Banking and Finance, 26(11), 2093-2110.

Altunbas, Y., Gambacorta, L., \& Marques-lbanez, D. (2009). Securitization and the bank lending channel. European Economic Review, 53(8), 996-1009.

Altunbas, Y., Gambacorta, L., \& Marques-lbanez, D. (2010). Bank risk and monetary policy. Journal of Financial Stability, 6(3), 121-129.

Apergis, N., \& Christou, C. (2015). The behaviour of the bank lending channel when interest rates approach the zero lower bound: Evidence from quantile regressions. Economic Modelling, 49(C), 296-307.

Arellano, M., \& Bond, S. R. (1991). Some tests of specification for panel data: Monte Carlo evidence and an application to employment equations. Review of Economic Studies, 58, 277297.

Arellano, M., \& Bover, O., (1995). Another look at the instrumental variables estimation of error components model. Journal of Econometrics, 68(1), 29-51.

Ariff, M. (2015). Islamic banking in Malaysia: Industry at crossroads. MGCC Perspectives, 21(4), 12-14.

Asbeig, H. I., \& Kassim, S. H. (2015). Monetary transmission during low interest rate environment in a dual banking system: Evidence from Malaysia. Macroeconomics and Finance in Emerging Market Economies, 8(3), 275-285.

Beck, T., Demirguc-Kunt, A., \& Merrouche, O. (2013). Islamic vs. conventional banking: Business model, efficiency, and stability. Journal of Banking and Finance, 37(2), 433-447.

Bernanke, B. S., \& Blinder, A. S. (1988). Credit, money, and aggregate demand. The American Economic Review, 78(2), 435439. 
Bhaumik, S. K., Dang, V., \& Kutan, A. M. (2011). Implications of bank ownership for the credit channel of monetary policy transmission: Evidence from India. Journal of Banking \& Finance, 35(9), 2418-2428.

Blundell, R., \& Bond, S. (1998). Initial conditions and moment restrictions in dynamic panel data models. Journal of Econometrics, 87(1), 115-143.

Bourkhis, K., \& Nabi, M. S. (2013). Islamic and conventional banks' soundness during the 2007-2008 financial crisis. Review of Financial Economics, 22(2), 68-77.

Cantero-Saiz, M., Sanfilippo-Azofra, S., Torre-Olmo, B., \& LopezGutierrez, C. (2014). Sovereign risk and the bank lending channel in Europe. Journal of International Money and Finance, 47, 1-20.

Cihak, M., \& Hesse, H. (2010). Islamic banks and financial stability: An empirical analysis. Journal of Financial Services Research, 38(2), 95-113.

Disyatat, P. (2011). The bank lending channel revisited. Journal of Money, Credit and Banking, 43(4), 711-734.

Domac, I. (1999). The distributional consequences of monetary policy: Evidence from Malaysia (World Bank Policy Research Working Paper No. 2170).

Ergec, E. H., \& Arslan, B. G. (2013). Impacts of interest rates on Islamic and conventional banks: The case of Turkey. Applied Economics, 45(17), 2381-2388.

Farooq, M., \& Zaheer, S. (2015). Are Islamic banks more resilient during financial panics? Pacific Economic Review, 20(1), 101124.

Gambacorta, L. (2005). Inside the bank lending channel. European Economic Review, 49(7), 1737-1759.

Gambacorta, L., \& Marques-lbanez, D. (2011). The bank lending channel: Lessons from the crisis. Economic Policy, 26(66), 135182. 
Hasan, M., \& Dridi, J. (2010). The effects of the global crisis on Islamic and conventional banks: A comparative study (IMF Working Paper WP/10/201).

Ibrahim, M. H. (2005). Sectoral effects of monetary policy: Evidence from Malaysia. Asian Economic Journal, 19(1), 83-102.

Ibrahim, M. H. (2016). Business cycle and bank lending procyclicality in a dual banking system. Economic Modelling, 55, 127-134.

Ibrahim, M. H., \& Sukmana, R. (2011). Dynamics of Islamic financing in Malaysia: Causality and innovation accounting. Journal of Asia-Pacific Business, 12(1), 4-19.

Jimborean, R. (2009). The role of banks in the monetary policy transmission in the EU member states. Economic Systems, 33(4), 360-375.

Kakes, J., \& Sturm, J. E. (2002). Monetary policy and bank lending: Evidence from German banking groups. Journal of Banking and Finance, 26(11), 2077-2092.

Kashyap, A. K., \& Stein, J. C. (2000). What do a million observations on banks say about the transmission of monetary policy. American Economic Review, 90(3), 407-428.

Kassim, S. H., Majid, M. S. A., \& Yusof, R. M. (2009). Impact of monetary policy shocks on the conventional and Islamic banks in a dual banking system: Evidence from Malaysia. Journal of Economic Cooperation and Development, 30(1), 41-58.

Khatat, M. E. (2016). Monetary policy in the presence of Islamic banking (IMF Working Paper WP/16/72).

Kishan, R. P., \& Opiela, T. (2000). Bank size, bank capital, and the bank lending channel. Journal of Money, Credit and Banking, 32(1), 121-141.

Kishan, R. P., \& Opiela, T. P. (2006). Bank capital and loan asymmetry in the transmission of monetary policy. Journal of Banking \& Finance, 30(1), 259-285.

Macit, F. (2012). Who responds more to monetary policy, conventional banks or participation banks?. Journal of Economics, Finance and Administrative Science, 17(33), 10-14. 
Matousek, R., \& Sarantis, N. (2009). The bank lending channel and monetary transmission in Central and Eastern European countries. Journal of Comparative Economics, 37(2), 321-334.

Olivero, M. P., Li, Y., \& Jeon, B. N. (2011). Consolidation in banking and the lending channel of monetary transmission: Evidence from Asia and Latin America. Journal of International Money and Finance, 30(6), 1034-1054.

Peek, J., \& Rosengren, E. (1995). Bank regulation and credit crunch. Journal of Banking \& Finance, 19(3-4), 679-692.

Perera, A., Ralston, D., \& Wickramanayake, J. (2014). Impact of offbalance sheet banking on the bank lending channel of monetary transmission: Evidence from South Asia. Journal of International Financial Markets, Institutions \& Money, 29, 195-216.

Roodman, D. (2009). A note on the theme of too many instruments. Oxford Bulletin of Economics and Statistics, 71(1), 135-158.

Seven U., \& Yetkiner, H. (2016). Financial intermediation and economic growth: Does income matter?. Economic Systems, 40, 3958.

Stein, J. C. (1998). An adverse-selection model of bank asset and liability management with implications for the transmission of monetary policy. The RAND Journal of Economics, 29(3), 466-486.

Sukmana, R., \& Kassim, S. H. (2010). Roles of Islamic banks in the monetary transmission process in Malaysia. International Journal of Islamic and Middle Eastern Finance and Management, 3(1), 7-19.

Windmeijer, F. (2005). A finite sample correction for the variance of linear efficient two-step GMM estimators. Journal of Econometrics, 126(1), 25-51.

Yang, J., \& Shao, H. (2016). Impact of bank competition on the bank lending channel of monetary transmission: Evidence from China. International Review of Economics \& Finance, 43, 468481. 
Zaheer, S., Ongena, S., \& van Wijnbergen, S. J. G. (2013). The transmission of monetary policy through conventional and Islamic banks. International Journal of Central Banking, 9(4), 175224.

Zulkhibri, M. (2013). Bank-characteristics, lending channel and monetary policy in emerging markets: Bank-level evidence from Malaysia. Applied Financial Economics, 23(5), 347-362. 
216 The Bank Lending Channel of Monetary Policy Transmission In a Dual Banking System

\section{APPENDIX}

Table 1.

Descriptive Statistics of Bank-Related Variables

\begin{tabular}{lcccccc}
\hline \multirow{2}{*}{ Variables } & \multicolumn{2}{c}{ All Banks } & \multicolumn{2}{c}{ Conventional Banks } & \multicolumn{2}{c}{ Islamic Banks } \\
\cline { 2 - 7 } & Mean & SD & Mean & SD & Mean & SD \\
\hline Loan Growth & 0.1298 & 0.2402 & 0.0939 & 0.2455 & 0.2075 & 0.2089 \\
Total Assets (In) & 15.4141 & 1.4420 & 15.5337 & 1.6290 & 15.1807 & 0.9412 \\
Equity:Assets & 10.8354 & 6.9248 & 11.7883 & 7.6499 & 8.9748 & 4.7233 \\
Liquid Assets & 30.7133 & 19.6186 & 32.7031 & 20.8811 & 26.8284 & 16.2601 \\
Funding Ratio & 72.5221 & 18.4766 & 68.8297 & 19.0942 & 79.7311 & 14.8037 \\
Loan Loss Reserve & 4.0760 & 3.7257 & 4.3241 & 4.0691 & 3.5664 & 2.8407 \\
\hline
\end{tabular}

Table 2.

Correlations

\begin{tabular}{lrrrrrrrrr}
\hline & $\Delta \ln (\mathrm{L})$ & \multicolumn{1}{c}{ SIZE } & EQA & LIQA & UND & \multicolumn{1}{c}{ LLRR } & $\Delta \ln (\mathrm{GDP})$ & INF & $\Delta \mathrm{R}$ \\
\hline$\triangle \ln (\mathrm{L})$ & 1.000 & & & & & & & & \\
SIZE & -0.028 & 1.000 & & & & & & & \\
EQA & -0.152 & -0.644 & 1.000 & & & & & & \\
LIQA & 0.051 & -0.519 & 0.412 & 1.000 & & & & & \\
FUND & 0.131 & 0.367 & -0.229 & -0.423 & 1.000 & & & & \\
LLRR & -0.132 & -0.180 & 0.138 & 0.249 & 0.111 & 1.000 & & & \\
$\triangle \ln (\mathrm{GDP})$ & 0.075 & 0.006 & 0.064 & 0.046 & 0.029 & -0.012 & 1.000 & & \\
INF & 0.100 & 0.008 & 0.007 & 0.094 & 0.034 & -0.091 & 0.324 & 1.000 & \\
$\triangle \mathrm{R}$ & 0.074 & 0.002 & 0.034 & 0.025 & 0.020 & 0.030 & 0.786 & 0.460 & 1.000 \\
\hline
\end{tabular}

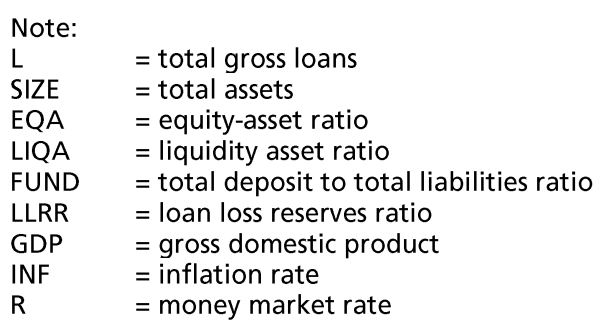




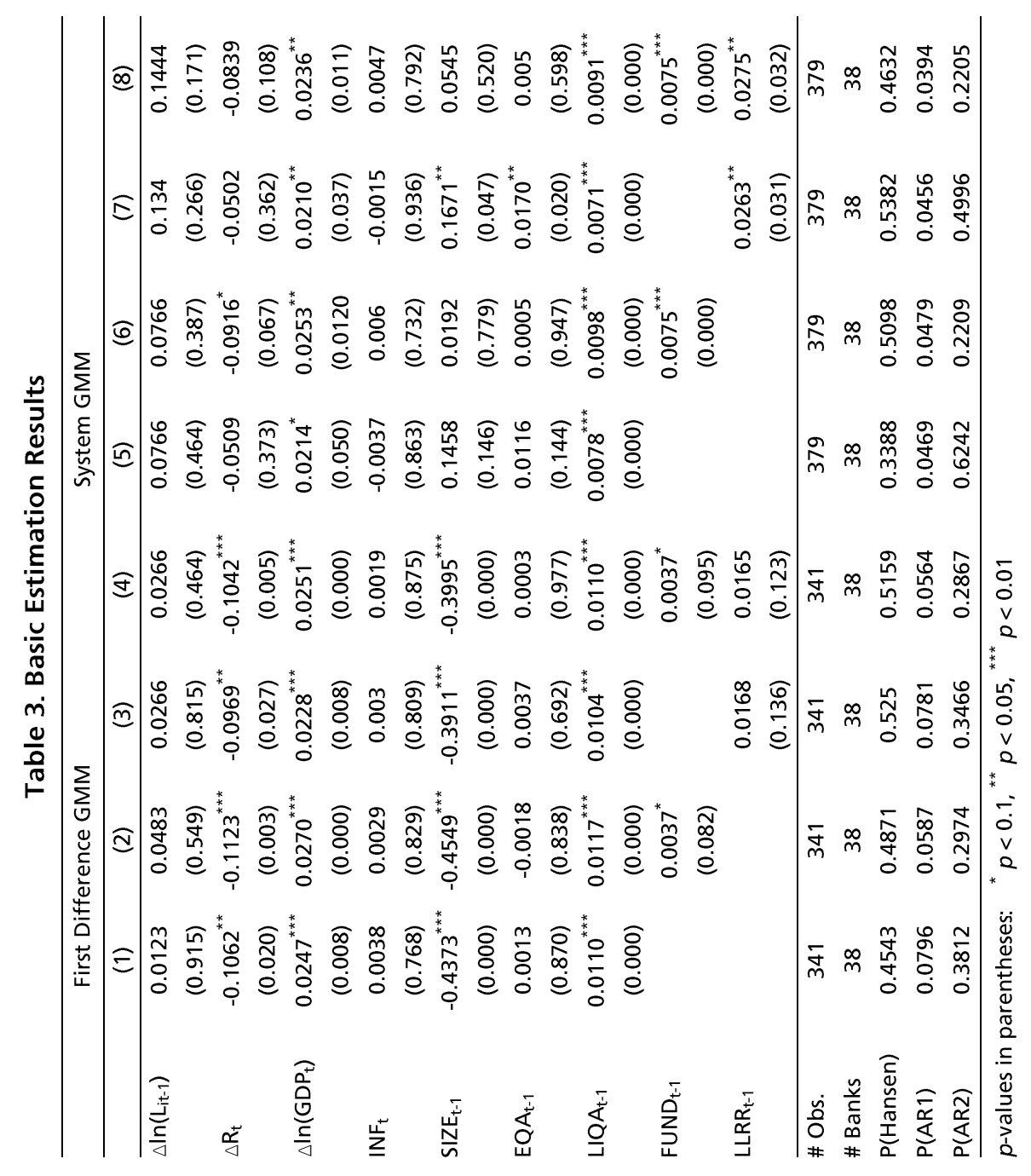




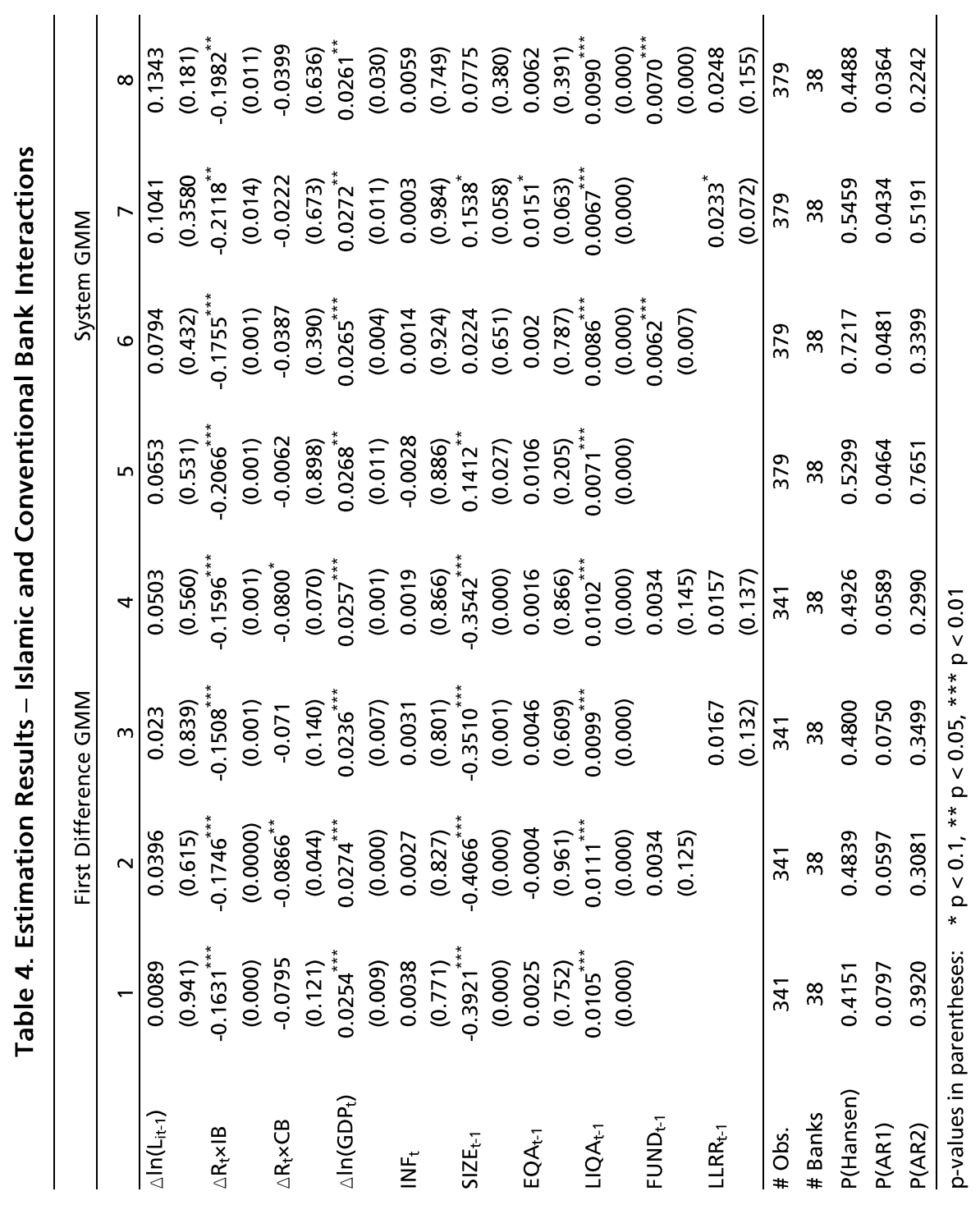




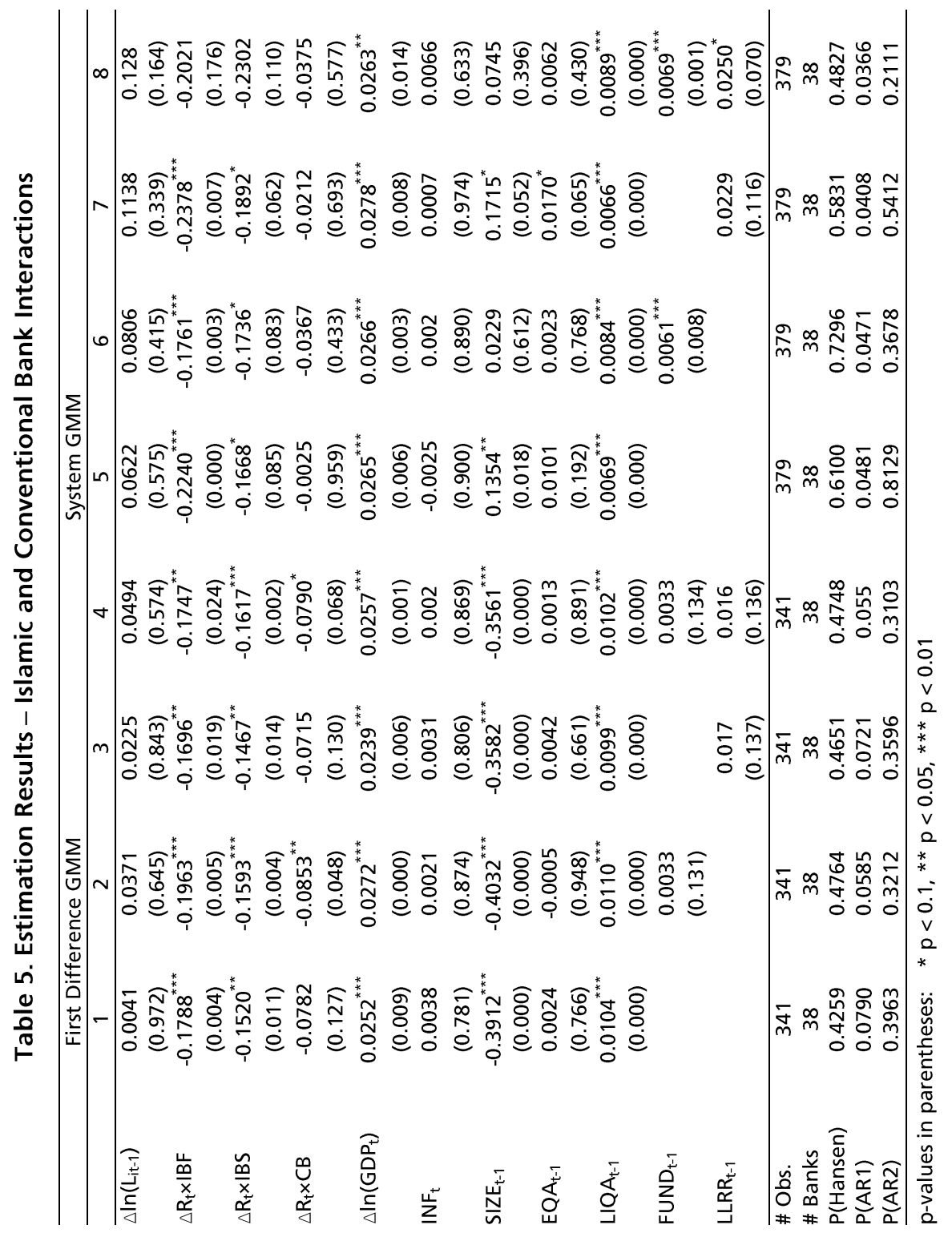




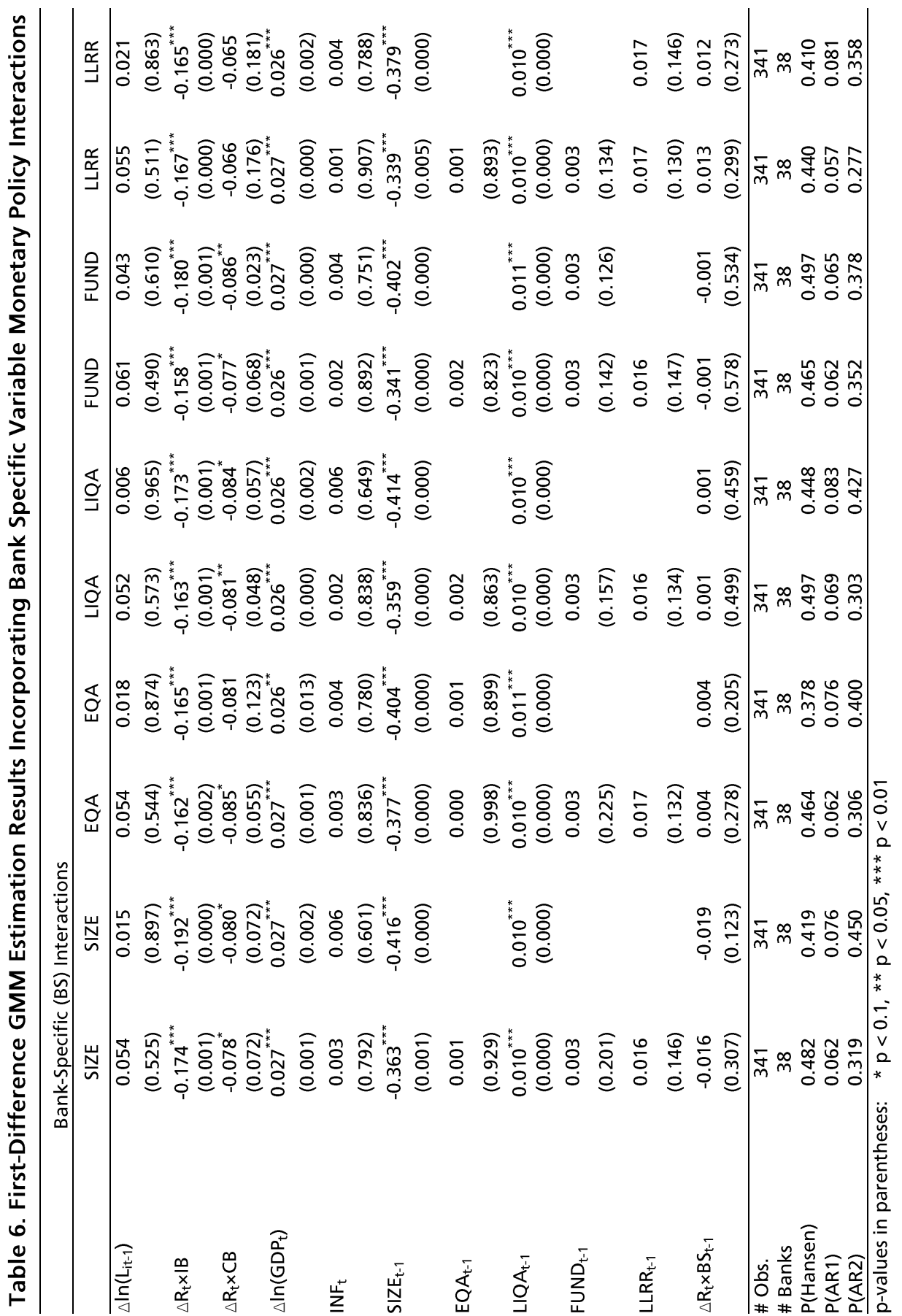

